\title{
Assessment of Primary Health Care Attributes in Campina Grande, Paraíba, Brazil
}

\author{
Avaliação dos atributos da atenção primária à saúde em Campina Grande, Paraíba, Brasil \\ Evaluación de los atributos de la Atención Primaria de Salud en Campina Grande, Paraíba, Brasil
}

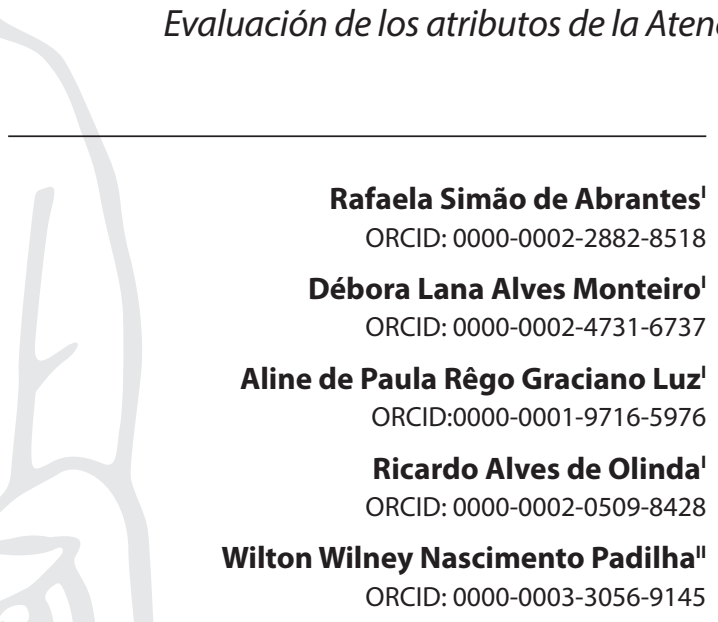

'Universidade Estadual da Paraíba. Campina Grande, Paraíba, Brazil.

"Universidade Federal da Paraíba. João Pessoa, Paraíba, Brazil.

How to cite this article: Abrantes RS, Monteiro DLA, Luz AP, Olinda RA, Padilha WWN. Assessment of Primary Health Care Attributes in Campina Grande, Paraíba, Brazil.

Rev Bras Enferm. 2020;73(Suppl 5):e20200128. doi: http://dx.doi.org/10.1590/0034-7167-2020-0128

Corresponding author:

Rafaela Simão de Abrantes

E-mail: rafaelaabrantes19@gmail.com

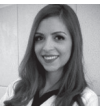

EDITOR IN CHIEF: Antonio José de Almeida Filho ASSOCIATE EDITOR: Ana Fátima Fernandes

Submission: $02-28-2020$

Approval: 06-14-2020

\begin{abstract}
Objective: to assess the presence and extent of Primary Health Care attributes in Campina Grande, Paraíba. Method: this is a cross-sectional study with 202 professionals from the Basic Health Units. The Primary Care Assessment Tool, Brazil, was used, which includes eight attributes of primary care whose scores were converted into a scale from 0 to 10 , with those considered satisfactory $>6.60$. Result: the general score mean was 7.6, but First contact access obtained a score of 3.7. Dental surgeons attributed the worst scores for all attributes $(p<0.05)$. Permanent education activity was associated with a high general score $(p<0.01)$. Conclusion: with the exception of First contact access, the other attributes are present, but initiatives by teams and managers are necessary for its expansion, with permanent education being the main strategy in this process.

Descriptors: Public Health; Primary Healthcare; Health Services Research; Health Personnel; Public Health Professional.
\end{abstract}

\section{RESUMO}

Objetivo: avaliar a presença e extensão dos atributos da Atenção Primária à Saúde de Campina Grande, Paraíba. Método: trata-se de um estudo transversal, com 202 profissionais das Unidades Básicas de Saúde. Foi utilizado o instrumento Primary Care Assessment Tool, Brasil, que contempla oito atributos da atenção primária cujos escores foram convertidos em escala de 0 a 10, sendo considerados satisfatórios aqueles $\geq 6,60$. Resultado: a média do Escore Geral foi de 7,6, mas a Acessibilidade de primeiro contato obteve escore de 3,7. Os cirurgiões dentistas atribuíram piores escores para todos os atributos $(p<0,05)$. A realização de atividade de educação permanente esteve associada ao Escore Geral alto $(p<0,01)$. Conclusão: com exceção da Acessibilidade de primeiro contato, os demais atributos estão presentes, mas iniciativas das equipes e gestores são necessárias para sua ampliação, sendo a educação permanente a principal estratégia nesse processo.

Descritores: Saúde Pública; Atenção Primária à Saúde; Avaliação de Serviços de Saúde; Profissionais de Saúde; Formação Profissional.

\section{RESUMEN}

Objetivo: evaluar la presencia y extensión de los atributos de la Atención Primaria de Salud em Campina Grande, Paraíba. Método: se trata de em rocess transversal em 202 profesionales de las Unidades Básicas de Salud. Se rocess la herramienta de evaluación de atención primaria, Brasil, que incluye ocho atributos de atención primaria cuyas puntuaciones se convirtieron em em escala de 0 a 10, considerándose aquellos> 6.60 son satisfactorios. Resultado: el promedio de la puntuación general fue de 7,6, pero la accesibilidad al primer contacto obtuvo em puntuación de 3,7. Los cirujanos dentales atribuyeron las peores puntuaciones para todos los atributos ( $p$ <05). El desempeño de la actividad de educación permanente se asoció em em puntaje general alto $(p<0.01)$. Conclusión: em la excepción de Accesibilidad para el primer contacto, los otros atributos están presentes, pero las iniciativas de los equipos y gerentes son rocessoa para su expansión, siendo la educación permanente la rocessoa principal em este rocesso.

Descriptores: Salud Pública; Atención Primaria de Salud; Personal de Salud; Capacitación Profesional. 


\section{INTRODUCTION}

Primary Health Care (PHC) must form the basis of the health system and the gateway to the service network, integrating and coordinating them to meet the most frequent health needs in the population ${ }^{(1)}$. PHC-oriented systems are known to contribute to improving health outcomes, access, equity and efficiency of services $^{(2-3)}$.

In Brazil, PHC services are structured according to the Brazilian Health System (Sistema Único de Saúde, abbreviated SUS) principles. In addition to these, to be characterized as a provider of quality $\mathrm{PHC}$, the Ministry of Health $(\mathrm{MoH})^{(4)}$ indicates the organization of these services in order to obtain four attributes, namely: essential attributes - first contact access, longitudinality, coordination of care, and comprehensiveness; and derived attributes - family orientation, community orientation, and cultural competence ${ }^{(1)}$.

These attributes can be assessed using the Primary Care Assessment Tool (PCATool), developed at Johns Hopkins University ${ }^{(5)}$. PCATool is presented in three original versions aimed at adult, child and professional users and/or managers. This study used the professional version, which was adapted and validated for Brazil( ${ }^{(6)}$.

In the international scenario, studies were found with PCAToolprofessionals by professionals from South Africa, China, Dominica and Chile $\mathrm{e}^{(7-10)}$. The overall performance verified in these countries was satisfactory. In China, general practitioner assessment obtained better results in relation to other $\mathrm{PHC}$ doctors ${ }^{(7)}$. Brazil has a higher concentration of these studies ${ }^{(11-21)}$, with a noticeable lack in northeastern Brazil ${ }^{(18)}$.

In a study of 8,234 Cuban doctors from the Programa Mais Médicos (More Doctors Program), a satisfactory overall performance of PHC was found, suggesting the impact of PHC training $^{(11)}$. Local studies have found an association of factors such as employment ${ }^{(12-13)}$, qualification focused on $\mathrm{PHC}^{(14)}$ and previous experience ${ }^{(15)}$ with PHC performance. However, other studies ${ }^{(16-17)}$ did not find any associations.

In this way, producing studies with PCATool-professionals can fill in the gaps about the professional context aspects that determine the quality of care assessment, relevant to the direction of investments aimed at improvement. Moreover, the complexity and heterogeneity of PHC assessment demands different perspectives, including that of professionals, enabling the production of rigorous knowledge about the effectiveness and diversity of services ${ }^{(4)}$.

Furthermore, this is the first study, so far, using PCAToolprofessionals in the state of Paraíba, collaborating to characterize these services in the country and providing unprecedented data for discussion in the academic environment and between managers and professionals.

Linked to this, assessment of quality of care is one of the performance indicators according to the new PHC financing model(22). Deepening assessment by professionals is important to support the future decision-making by SUS managers and workers.

Considering the above, it is expected that the findings may support interventions that aim to reduce problems related to PHC attributes, such as organizational failures of services and inadequacies in the teams' work process, as well as enhance those well-assessed attributes.

\section{OBJECTIVE}

To assess the presence and extent of $\mathrm{PHC}$ attributes in all Basic Health Units (BHU) in the city of Campina Grande, PB.

\section{METHODS}

\section{Ethical aspects}

This study was approved by the Research Ethics Committee of Universidade Estadual da Paraíba. Participants signed the Informed Consent Form. Ethical precepts were respected, according to Resolution 466/2012(23).

\section{Design, place of study, and period}

This is a quantitative and cross-sectional study ${ }^{(24)}$ carried out in all BHU in Campina Grande, PB. The municipality has an estimated population of 409,731 inhabitants and a land area of $593,026 \mathrm{~km}^{2(25)}$, being one of the 14 pioneers in implementing the Family Health Program (FHP), with $81 \mathrm{BHU}^{(26)}$, whose Family Health Strategy (FHS) coverage is $91.78 \%{ }^{(27)}$. Data collection took place from July to December 2019.

\section{Sample, and inclusion and exclusion criteria}

The sample was a non-probabilistic type, composed of health professionals from the BHU of Campina Grande who met the inclusion criteria. According to the SUS Computer Department (Departamento de Informática do SUS, abbreviated DATASUS), in December 2019, the municipality had 49 dental surgeons, 98 doctors and 116 nurses, totaling 263 professionals ${ }^{(26)}$, of whom 220 were eligible for the study (46 dental surgeons), 81 doctors and 93 nurses). The questionnaire was applied to 202 professionals (44 dental surgeons, 70 doctors and 88 nurses). The loss rate was $8.63 \%(n=18)$, including refusals $(n=10)$, failure after 4 attempts $(n=6)$ and invalid questionnaires $(n=2)$.

The inclusion criteria adopted were: being a doctor, dentist or nurse at the BHU; have been on the same team for at least six months; and work hours equal to or greater than 20 hours per week. Those on vacation and/or leave were excluded.

\section{Study protocol}

The questionnaires were applied in the BHU by three trained researchers, after prior appointment, during the professional's working hours and in a private room. The questionnaires were divided into: Part 1 - Questionnaire with sociodemographic and professional context information; Part 2- Primary Care Assessment Instrument (Instrumento de Avaliação da Atenção Primária) (PCATooL-Brazilprofessionals), consisting of 77 items grouped into 8 components that include PHC attributes. The instrument is organized as follows ${ }^{(4)}$ :

1. First contact access - Accessibility (A). Made up of 9 items (A1 to A9), which seek to check the availability and functioning of services regarding length, days of operation, and existence of communication channels, in addition to the ease for users to obtain consultation and the waiting time. 
2. Longitudinality (B). Made up of 13 items (B1 to B13), which address questions about the bond between professional and patient, including characteristics of communication with each other, knowledge about the health and social condition of patients and whether it is always attended by the same professional.

3. Coordination - Integration of care (C). Made up of 6 items (C1 to C6), they seek to know if the professional is aware of patients' consultations with specialists and if information is sent and received from them, in addition to the help of someone from the service for patients to schedule an appointment.

4. Coordination - Information system (D). Made up of 3 items (D1 to D3), which seek to know if the clinical information, treatment and patient consultations are organized and properly registered and if they are easily accessible to users.

5. Comprehensiveness - Services available (E). Made up of 22 items (E1 to E22), which seek to identify whether the service offers a series of procedures such as immunizations, dental treatment, nutritional counseling, preventive exam, among others.

6. Comprehensiveness - Services provided (F). Made up of 15 items (F1 to F15), which seek to know if professionals discuss certain preventive and health promotion issues with patients.

7. Family orientation (G). Made up of 3 items ( $G 1$ to $G 3$ ), which seek to know if the professional takes into account the family context in planning and treating patients, including their opinions and family health history.

8. Community orientation (H). Made up of 6 items ( $\mathrm{H} 1$ to $\mathrm{H} 6)$, which seek to know if professionals consider the context of the community when planning actions through home visits, satisfaction surveys and to identify problems.

The answers for each item are presented on a Likert scale, with scores ranging from 0 to 4 ( $4=$ =certainly yes; $3=$ probably yes; $2=$ probably no; $1=$ certainly no; $9=$ no I don't know/don't remember, the latter later converted to the value 2). The score of each attribute was calculated by the simple arithmetic mean of the values of each answer. The values of each item on the scale, ranging from 1 to 4 , were transformed into a continuous scale from 0 to 10 using the formula:

Score 0 to 10 of attribute $X=\frac{\text { (score } 1 \text { to } 4 \text { of attribute } X-1) \times 10}{3}$

The essential score was calculated by adding the mean scores of their respective components, divided by the number of components, as in the formulas below:

Essential Score $=\frac{(A+B+C+D+E+F)}{6}$

The general score was calculated by adding the mean score of the components of the essential and derived attributes, divided by the total of components.

General Score $=\frac{(A+B+C+D+E+F)+(G+H)}{8}$

Scores with values equal to or above 6.6 were considered satisfactory ${ }^{(6)}$, corresponding to responses greater than or equal to 3 ("probably yes") on the Likert scale.

\section{Analysis of results}

Data were entered into Excel, Microsoft Office 2016 spreadsheets and later exported and analyzed using the R Core Team Statistical Software program. The attributes scores were presented as means and medians, according to their distribution. For their comparisons according to the professional category, the parametric Student's $\mathrm{t}$ test and the non-parametric test by Man Whitney were used. Pearson's chi-square test was used to associate professional context variables with the general score (high/low). In the multivariate analysis, verification of factors associated with the high general score was based on prevalence ratios (PR) and their respective confidence intervals $(95 \% \mathrm{Cl})$, estimated by Poisson Regression. Variables associated with the high general score with $p<0.20$ were included in the crude and adjusted analysis. For all analyzes, a significance level of $5 \%$ was used.

\section{RESULTS}

In this study, 202 health professionals were interviewed, distributed among nurses $(43.6 \% ; n=88)$, doctors $(34.6 \%, n=70)$ and dental surgeons $(21.8 \% ; n=44)$ who worked at the $\mathrm{BHU}$ of Campina Grande. Table 1 shows the distribution of the high and low general scores according to sociodemographic characteristics and professional context.

The mean age was 42.76 , ranging from 24 to 74 years and predominantly composed of females ( $n=173,86.5 \%$ ). Regarding the characteristics of training and professional education, the median of time passed after graduation was 16 years $(S D=12.26)$, with professionals who graduated from a public institution (71.78\%), completed or were studying some type of graduate degree in PHC (77.2\%), of which specialization was the most frequent type (58.91\%). Most also stated that they had performed or were performing permanent education activities (76.73\%).

Regarding work, the median length of work at $\mathrm{PHC}$ was 14 years $(S D=9.41)$ and 4 years $(S D=4.92)$ for team performance length. Furthermore, $50.99 \%$ were statutory; $52.97 \%$ said they did not have or were not sure on the existence of municipal incentive to permanent education; and $94.55 \%$ worked a 40 -hour weekly day.

Table 2 presents the minimum, maximum, mean, median and standard deviation values of the scores of PHC attributes, according to $\mathrm{BHU}$ professionals.

The scores showed satisfactory values (> 6.6), except for First contact access (Table 2). Table 3 below shows the attribute scores for each professional category.

Analysis by professional category found that dentists attributed lower values. The observed differences were significant for Longitudinality, Coordination - information system, Comprehensiveness - services provided, Family orientation, as well as for essential, variate, and general scores (Table 3). The variables that maintained associations with high General Score in the final model are shown in Table 4.

It was found that the prevalence of the high general score was higher among doctors and nurses and those who claimed to carry out permanent education activity $(p<0.05)$. The other variables did not show a statistically significant association (Table 4). 
Table 1 - Distribution of the high and low general scores according to sociodemographic and professional context variables of Basic Health Units professionals, Campina Grande, Paraíba, Brazil, 2020

\begin{tabular}{|c|c|c|c|c|c|}
\hline \multirow{2}{*}{ Variable } & \multicolumn{2}{|c|}{ Low General Score } & \multicolumn{2}{|c|}{ High General Score } & \multirow[t]{2}{*}{$p^{*}$} \\
\hline & $\mathbf{n}$ & $\%$ & $n$ & $\%$ & \\
\hline \multicolumn{6}{|l|}{ Sex } \\
\hline Male & 7 & 12.30 & 22 & 15.20 & 0.5978 \\
\hline Female & 50 & 87.70 & 123 & 84.80 & \\
\hline \multicolumn{6}{|l|}{ Age } \\
\hline$>40$ years old & 32 & 56.10 & 68 & 46.90 & 0.2369 \\
\hline$\leq 40$ years old & 25 & 43.90 & 77 & 53.10 & \\
\hline \multicolumn{6}{|l|}{ Category } \\
\hline Nurse & 18 & 31.60 & 70 & 48.30 & $<0.01$ \\
\hline Doctor & 17 & 29.80 & 53 & 36.60 & \\
\hline Dental surgeon & 22 & 38.60 & 22 & 15.20 & \\
\hline \multicolumn{6}{|l|}{ Institution } \\
\hline Public & 44 & 77.20 & 101 & 69.70 & 0.284 \\
\hline Private & 13 & 22.80 & 44 & 30.30 & \\
\hline \multicolumn{6}{|c|}{ Time passed after graduation } \\
\hline$\geq 16$ years & 34 & 59.60 & 65 & 44.80 & 0.0578 \\
\hline$<16$ years & 23 & 40.40 & 80 & 55.20 & \\
\hline \multicolumn{6}{|l|}{ Work location } \\
\hline Urban & 53 & 93.00 & 128 & 88.30 & 0.733 \\
\hline Mixed & 2 & 3.50 & 7 & 4.80 & \\
\hline Rural & 2 & 3.50 & 10 & 6.90 & \\
\hline \multicolumn{6}{|l|}{ Graduate } \\
\hline Yes & 41 & 71.90 & 115 & 79.30 & 0.2602 \\
\hline No & 16 & 28.10 & 30 & 20.70 & \\
\hline \multicolumn{6}{|l|}{ Type of graduate } \\
\hline Specialization & 34 & 59.60 & 85 & 58.60 & 0.6419 \\
\hline Master's degree & 3 & 5.30 & 14 & 9.70 & \\
\hline Doctoral degree & 0 & 0.00 & 2 & 1.40 & \\
\hline Residency & 4 & 7.00 & 14 & 9.60 & \\
\hline None & 16 & 28.10 & 30 & 20.70 & \\
\hline \multicolumn{6}{|l|}{ Permanent education } \\
\hline Yes & 36 & 63.20 & 119 & 82.10 & $<0.01$ \\
\hline No & 21 & 36.80 & 26 & 17.90 & \\
\hline \multicolumn{6}{|l|}{ Length of work at PHC } \\
\hline$\geq 14$ years & 29 & 50.90 & 68 & 46.90 & 0.6102 \\
\hline$<14$ years & 28 & 49.10 & 77 & 53.10 & \\
\hline \multicolumn{6}{|l|}{ Team length } \\
\hline$\geq 4$ years & 29 & 50.90 & 71 & 49.00 & 0.8067 \\
\hline$<4$ years & 28 & 49.10 & 74 & 51.00 & \\
\hline \multicolumn{6}{|c|}{ Employment relationship } \\
\hline Statutory & 30 & 52.60 & 73 & 50.30 & 0.5125 \\
\hline Contract & 23 & 40.40 & 51 & 35.20 & \\
\hline Residency & 2 & 3.50 & 7 & 4.80 & \\
\hline Scholarship holder & 2 & 3.50 & 14 & 9.70 & \\
\hline \multicolumn{6}{|l|}{ Workload } \\
\hline$<40$ hours & 2 & 3.50 & 9 & 6.20 & 0.5509 \\
\hline$>40$ hours & 55 & 96.40 & 136 & 93.80 & \\
\hline \multicolumn{6}{|l|}{ Municipal incentive } \\
\hline Yes & 26 & 45.60 & 69 & 47.60 & 0.5685 \\
\hline No & 25 & 43.90 & 54 & 37.20 & \\
\hline Not sure & 6 & 10.50 & 22 & 15.20 & \\
\hline
\end{tabular}

Note: *Pearson's chi-square test. Primary Health Care.

Table 2 - Distribution of the minimum, maximum, mean, and median values of Primary Health Care attributes according to professionals in Basic Health Units, Campina Grande, Paraíba, Brazil, 2020

\begin{tabular}{lcccc}
\hline Primary Health Care Attributes & \multicolumn{1}{c}{ Minimum } & Maximum & Mean $^{\dagger} /$ Median* $^{*}$ & SD \\
\hline First contact access* $^{*}$ & 1.48 & 6.67 & 3.70 & 1.12 \\
Longitudinality* $^{*}$ & 4.87 & 10.00 & 7.39 & 1.17 \\
Coordination - integration of care* $^{*}$ & 3.89 & 10.00 & 7.22 & 1.34 \\
Coordination - information systems* $^{*}$ & 3.33 & 10.00 & 8.88 & 1.53 \\
Comprehensiveness - services available $^{\dagger}$ & 2.73 & 10.00 & 6.96 & 1.20 \\
Family orientations $^{*}$ services provided** & 0.22 & 10.00 & 7.88 & 1.86 \\
Community orientation* $^{*}$ & 3.33 & 10.00 & 8.88 & 1.62 \\
Essential Score $^{\dagger}$ & 2.78 & 10.00 & 7.22 & 1.66 \\
Variate Score $^{\dagger}$ & 4.69 & 9.30 & 6.89 & 0.89 \\
General Score $^{\dagger}$ & 3.33 & 10.00 & 7.77 & 1.36 \\
& 4.77 & 9.72 & 7.16 & 0.98 \\
\hline
\end{tabular}

\section{DISCUSSION}

Assessment of PHC services allows the verification of barriers and factors associated with the achievement of PHC attributes. For this, it should be considered that, in practice, these attributes are interrelated ${ }^{(1)}$, and the results found should not be interpreted in isolation.

Thus, this study found a satisfactory general score, but worse assessments by dental surgeons, in addition to the existence of weaknesses in First contact access and in some specific items of the other attributes, discussed later.

First contact access had a score of 3.83. This finding corroborates national studies carried out in São Paulo ${ }^{(15,19)}$, Goiás ${ }^{(17)}$, and Espírito Santo ${ }^{(20)}$, whose scores were 2.84; $3.71 ; 3.97$ and 5.57, respectively. This was the only attribute with an unsatisfactory score, as in the present study.

The essential score found in the current study was 6.89 , and 7.16 for the general score. However, in another study conducted in Ceará, all attributes were negatively assessed, with an essential score of 6.05 and a general score of $6.35^{(18)}$.

Despite the concentration of studies in the Southeast ${ }^{(15,19-20)}$ and South ${ }^{(12,21)}$ regions, negative assessments for First contact access were unanimous. This is the case of studies in Rio Grande do Sul and Ceará, which had a general score of $7.52^{(12)}$ and $6.49^{(18)}$, respectively, but both found a negative assessment of accessibility. In contrast, in China ${ }^{(7)}$ and South Africa ${ }^{(8)}$ this attribute was present. As there is no internationally standardized scale for PCATool scores, these studies adopted their own scale.

In fact, evident barriers of access such as lack of operation during night hours, the offer of assistance on weekends and the absence of a telephone for communication, are verified in most of these Brazilian services $^{(28)}$. Despite the Brazilian National Primary Care Policy (Política Nacional de Saúde, abbreviated PNAB) recommending the organization of the aforementioned according to the population's access needs ${ }^{(29)}$, this has not been sufficient to drive changes in the institutional culture already established ${ }^{(28)}$. Moreover, the expansion of FHS coverage over the years, reaching $64.67 \%$ in $2019^{(27)}$, has been compromised by the reduction of federal investment in health since $2015^{(30)}$. 
Table 3 - Comparison of means and medians of attribute scores between the Basic Health Units professional categories, Campina Grande, Paraíba, Brazil, 2020

\begin{tabular}{|c|c|c|c|c|c|c|}
\hline \multirow{2}{*}{ Primary Health Care Attributes } & \multicolumn{2}{|c|}{ Dental Surgeon } & \multicolumn{2}{|c|}{ Nurse } & \multicolumn{2}{|c|}{ Doctor } \\
\hline & Mean*/Median ${ }^{\dagger}$ & $(95 \% \mathrm{CI}) / \mathrm{II}$ & Mean*/Median ${ }^{+}$ & $(95 \% \mathrm{CI}) / \mathrm{II}$ & Mean*/Median ${ }^{\dagger}$ & $(95 \% \mathrm{CI}) / \mathrm{II}$ \\
\hline Accessibility $^{\dagger}$ & $3.33 a$ & $2.96-4.53$ & $3.70 a$ & $2.96-4.44$ & $3.88 a$ & $2.96-4.72$ \\
\hline Longitudinality* & $7.00 \mathrm{~b}$ & $6.67-7.33$ & $7.55 a$ & $7.32-7.79$ & $7.48 a$ & $7.18-7.78$ \\
\hline Coordination - integration of care* & $6.99 a$ & $6.57-7.41$ & $7.22 \mathrm{a}$ & $6.93-7.52$ & $7.14 a$ & $6.84-7.45$ \\
\hline Coordination - information systems ${ }^{\dagger}$ & $7.78 b$ & $6.67-8.89$ & $8.89 a$ & $7.78-10.0$ & $8.89 a$ & $7.78-10.0$ \\
\hline Comprehensiveness - services available* & $7.16 a$ & $6.81-7.50$ & $6.89 a$ & $6.61-7.17$ & $6.94 a$ & $6.68-7.20$ \\
\hline Comprehensiveness - services provided $\dagger$ & $5.55 b$ & $4.61-7.11$ & $8.22 a$ & $7.33-9.11$ & $8.33 a$ & $7.11-9.11$ \\
\hline Family orientation $^{\dagger}$ & $8.34 \mathrm{~b}$ & $6.67-8.89$ & $8.89 a$ & $7.78-10.0$ & $9.45 a$ & $7.78-10.0$ \\
\hline Community orientation* & $6.77 a$ & $6.15-7.38$ & $7.38 \mathrm{a}$ & $7.07-7.69$ & $7.17 a$ & $6.78-7.57$ \\
\hline Essential Score* & $6.32 b$ & $6.08-6.57$ & $7.06 a$ & $6.87-7.24$ & $7.05 a$ & $6.85-7.25$ \\
\hline Variate Score* & $6.56 \mathrm{~b}$ & $6.27-6.85$ & $7.29 a$ & $7.11 ; 7.48$ & $7.28 \mathrm{a}$ & $7.07-7.48$ \\
\hline General Score* & $7.26 \mathrm{~b}$ & $6.75-7.77$ & $8.00 a$ & $7.74-8.26$ & $7.95 a$ & $7.65-8.26$ \\
\hline
\end{tabular}

Notes: (95\% Cl) - 95\% Confidence Interval (mean); II - Interquartile range (median); ${ }^{*}$ Student's t test for variables with normal distribution (mean); ${ }^{\dagger}$ Man-Whitney test for variables with abnormal distribution (median); $a$ - without statistically significant difference; $b$ - statistically significant difference $(p<0.05)$.

Table 4 - Crude and adjusted regression for the general Primary Health Care score attributed by Family Health Strategy professionals, Campina Grande, Paraíba, Brazil, 2020

\begin{tabular}{|c|c|c|c|c|}
\hline \multirow{2}{*}{ Variable } & \multicolumn{4}{|c|}{ High General Score } \\
\hline & $\mathrm{CPR}^{*} /(95 \% \mathrm{Cl})$ & $\operatorname{adjPR}{ }^{\dagger} /(95 \% \mathrm{Cl})$ & P (Wald's test) & $P$ (LR-test) \\
\hline Category & & & & 0.035 \\
\hline Doctor & $1.51(0.92-2.49)$ & $1.22(1.01-1.49)$ & 0.042 & \\
\hline Nurse & $1.59(1.01-2.57)$ & $1.33(1.08-1.63)$ & 0.029 & \\
\hline Dental surgeon & 1 & 1 & & \\
\hline Time passed after graduation & & & & 0.576 \\
\hline$<16$ years & $1.18(0.85-1.64)$ & & 0.576 & \\
\hline$>16$ years & 1 & 1 & & \\
\hline Permanent education & & & & 0.046 \\
\hline Yes & $1.39(0.91-2.12)$ & $1.35(1.03-1.76)$ & 0.047 & \\
\hline No & 1 & 1 & & \\
\hline Employment relationship & & & & 0.965 \\
\hline Statutory & $1.03(0.72-1.47)$ & $1.05(0.67-1.64)$ & 0.965 & \\
\hline Scholarship holder (PMM) & $1.27(0.71-2.29)$ & $1.18(0.61-2.26)$ & 0.625 & \\
\hline Resident & $1.13(0.51-2.48)$ & $0.99(0.42-2.33)$ & 0.992 & \\
\hline Hired & 1 & & & \\
\hline Municipal incentive & & & & 0.781 \\
\hline Yes & $1.06(0.74-1.52)$ & $0.99(0.68-1.43)$ & 0.937 & \\
\hline Not sure & $1.15(0.7-1.89)$ & $1.17(0.7-1.96)$ & 0.539 & \\
\hline No & 1 & 1 & & \\
\hline
\end{tabular}

Ceará (6.05) $)^{(18)}$, Goiás (6.8)(17), São Paulo $(7.0)^{(19)}$, and Espírito Santo $(7.99)^{(15)}$.

A high percentage of professionals responded negatively to the items about the knowledge of patients' employment and housing, pointing out the need for a closer relationship with the reality of users. Furthermore, the success of longitudinality also depends on the coordination of care, including the quality of information and its fluidity between services ${ }^{(32)}$.

In this sense, the attributes Coordination - integration of care and Coordination - information system obtained satisfactory mean scores (7.14 and 8.44, respectively). The high score of these attributes is probably explained by the existence of electronic medical records in the municipality, standing out as a relevant tool in coordination of care.

However, there was a high prevalence of negative responses in the item about

Although these PCATooL issues have been identified as inadequate to the Brazilian reality ${ }^{(18)}$, they reflect the extent to which these services still need to advance in order to adapt to an ideal $\mathrm{PHC}$ model, starting with increasing service coverage, expanding the functioning of units and non-face-to-face communication

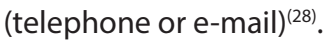

Access to services can be enhanced by overcoming the agendas organized strictly by preferential groups, which is very common in the municipality studied, and which compromise the spontaneous demand of the population in general. One of these strategies is advanced access, which allows appointment schedule for the same day or within 48 hours ${ }^{(31)}$.

The guarantee of accessibility in PHC is essential for the use of these services as a regular source, relevant to the achievement of longitudinality ${ }^{(1)}$, which presented a high mean score (7.4). A nationally-based study found scores of 8.1 in the Northeast and South, and 7.9 in the Southeast and North ${ }^{(11)}$. It is possible that the training focused on PHC of Cuban doctors in this study influenced the results verified, since they were higher than those verified in receiving information from patients in specialized services, also found in studies in South Africa ${ }^{(8)}$ and Chile ${ }^{(10)}$. In Brazil, the same occurred in Ceará(33) and São Paulo ${ }^{(20)}$, highlighting the need to strengthen communication mechanisms between services through the creation of standardized reference and counterreference protocols.

It was also found that, in the municipality assessed, some clinical procedures are moved to other services. In fact, $\mathrm{PHC}$ resolution is one of the challenges recognized in SUS ${ }^{(32) .}$ In this context, the attribute Comprehensiveness - services available scored 6.96. Individual analysis of the items showed that procedures such as wart removal, suturing in cases of cut and ingrown nail removal are practically not offered in the units; and this occurred in other national studies ${ }^{(15,18)}$, unlike countries like China ${ }^{(7)}$ and Chile $^{(10)}$ that were considerably satisfactory in this regard.

Some of the possible related factors are structural inadequacy; the disabling of a guide or portfolio of services by managers and professionals who determine the procedures inherent to PHC; and the imprecision of the roles of each professional in offering 
these procedures ${ }^{(34)}$. In fact, a study in Campina Grande found structural conditions that were not very favorable in $\mathrm{PHC}^{(35)}$. Furthermore, the lack of definition is noticeable, as there were occasional cases of professionals who claimed to perform such procedures while most do not.

In turn, Comprehensiveness - services provided obtained a satisfactory assessment (7.56). However, the negative assessment predominated in the item that deals with the professionals'knowledge about the possession and safety of firearms by patients. Similar results were found in South Africa ${ }^{(8)}$ and Chile ${ }^{(10)}$, which performed poorly. The mean of the attribute scores in national studies was 6.74 in Ceará(16); 7.2 in Rio Grande do Sul(28); and 8.4 in São Paulo(27), all with a negative rating on the issue involving firearms.

Recognizing the potential of PHC in the prevention of health problems and health promotion and considering the seriousness of firearm accidents, it seems pertinent that this topic be addressed in PHC. In fact, the Primary Care Services Portfolio (Carteira de Serviços da Atenção Primária) (2019) mentions the prevention of firearm accidents, referring to the Primary Care Notebook (Caderno de Atenção Básica) (2012)(36). However, no references were found at the state and municipal levels to indicate this theme in PHC.

The attributes Family orientation and Community orientation obtained mean scores of 8.47 and 7.17, respectively. In China, Community orientation presented negative assessments by nongeneral practitioners in relation to general practitioners ${ }^{(7)}$. In the state of Pernambuco, the scores were 6.4 and 7.93, respectively, with a negative result for the item on the presence of users in health councils(37) as well as in this research. The need for actions that encourage community empowerment and promote greater control of public health policies by users was evidenced, as advocated by the Brazilian National Health Promotion Policy (Política Nacional de Promoção da Saúde) ${ }^{(38)}$.

Regarding the scores of each attribute, according to the professional category, dentists were the ones who attributed the worst values. This difference was statistically significant $(p<0.05)$ for the attributes Longitudinality, Coordination of care - information system, Comprehensiveness - services provided, Family orientation and for essential, varied and general scores. The adjusted multivariate analysis confirmed that dental surgeons obtained lower prevalence of the general high score in relation to doctors and nurses ( $p<0.05)$.

The results obtained from dental surgeons converge with that found in Ceará(18). In the state of Rio Grande do Sul, these professionals also had a higher proportion of the low overall score $^{(13)}$. Despite the lack of studies with the PCATool applied to this category, nursing literature has reported challenges to be faced in overcoming the traditional dental model. The insufficiency in carrying out actions that involve family orientation ${ }^{(39)}$, coordination of care ${ }^{(39-40)}$ and comprehensiveness ${ }^{(39)}$ stood out, supporting the performances found here.

However, it was found that the PCATool was not suitable for assessing specific assignment services for the dental surgeon, especially in the attribute Comprehensiveness - services provided. This attribute had a worse performance, possibly due to the content of the questions related to the medical and nursing routine. Therefore, it is suggested to adapt this instrument to the context of oral health.
As for permanent education, a variable associated with high general score ( $p<0.001$ ), it stands out as a strategy to qualify the work processes by problematizing the practice scenarios. Despite the scarcity of studies on its practical implications ${ }^{(41)}$, a study in Paraíba found that this strategy was able to improve access, strengthen the bond with users and community participation ${ }^{(42)}$, thus indicating the potential to impact on PHC attributes.

In Paraíba, the main permanent education initiatives include seminars, workshops, matrix support, specialization courses, training and those of teaching-service integration, such as the Education through Work for Health Program (Programa de Educação pelo Trabalho para a saúde, abbreviated PET-Saúde), supported by state management, which seems to lead these actions, according to the needs of the health regions ${ }^{(43)}$. Despite the relevance, $53 \%$ of the professionals who participated in this study said they were unaware of or did not receive municipal support for permanent education, demonstrating a worrying insufficiency of these actions.

A study carried out in Belo Horizonte found that the highest proportion of professionals trained in family health was one of the factors most strongly associated with better PHC performance. (14). In Goiânia, there was no association between family health training and the quality of these services ${ }^{(16)}$. It is possible that the conceptual difficulties of permanent education, confused with continuing education ${ }^{(41)}$, may lead to overestimated and/or distinct results, requiring further studies on their impact on $\mathrm{PHC}$.

\section{Study limitations}

In addition to the limitations inherent in cross-sectional research, studies are suggested that also address the users' experiences. Gathering specific aspects of professional qualification related to the performance of services was limited, but the findings brought important notes that require further study.

\section{Contributions to nursing, health, and public policies}

The results of this research should be taken to managers and professionals, as they guide necessary changes and bring up reflections on the existing weaknesses in the training and performance aimed at PHC; they alert to the creation of local strategies that can impact the reorientation of the work process. The findings will also be shared with higher education institutions in Paraíba, considering their predominant role in the training and permanent education of professionals.

\section{CONCLUSIONS}

This study found limits and potentialities in the performance of the PHC attributes, directing necessary initiatives for the improvement of services. Among the main limitations are the low performance in the attribute First contact access and the worst assessments attributed by dental surgeons. Despite this, the overall assessment was positive and the other attributes are present, indicating the potential of the current care model.

To achieve these attributes more, internal strategies are needed in the work process of the teams, ranging from the expansion of the practice guided by comprehensive care to the improvement of the service organization to meet the demands. Managers are 
responsible for ensuring minimum structural conditions and greater investments in permanent education to guarantee the qualification of human resources and the reach of changes.
The present study achieved its objective while enabling knowledge about the presence and extension of the attributes, pointing out the main flaws and strategies for their resolution.

\section{REFERENCES}

1. Starfield B. Atenção Primária: equilíbrio entre necessidades de saúde, serviços e tecnologia[Internet] Brasília (DF): Unesco, Ministério da Saúde; 2002[cited 2019 Oct 10]. 726 p. Available from: https://www.nescon.medicina.ufmg.br/biblioteca/imagem/0253.pdf

2. Kringos DS, Boerma WGW, Hutchinson A, van der Zee J, Groenewegen PP. The breadth of primary care: a systematic literature review of its core dimensions. BMC Health Serv Res. 2010;10(65). doi: 10.1186/1472-6963-10-65

3. Bastos ML, Menzies D, Hone T, Dehghani K, Trajman A. Correction: the impact of the Brazilian family health on selected primary care sensitive conditions: a systematic review. PLoS One. 2017;12(12):e0189557. doi: /10.1371/journal.pone.0189557

4. Ministério da Saúde (BR). Secretaria de Atenção em Saúde, Departamento de Atenção Básica. Manual do instrumento de avaliação da atenção primária à saúde: primary care assessment tool pcatool - Brasil [Internet]. Brasília: Ministério da Saúde; 2010 [cited 2019 Oct 10]. 80 p. Available from: http://bvsms.saude.gov.br/bvs/publicacoes/manual_avaliacao_pcatool_brasil.pdf

5. Shi L, Starfield B, Xu J. Validating the Adult Primary Care Assessment Tool. J Fam Prac [Internet]. 2001 [cited 2019 Oct 10];50(2):161-75. Available from: https://www.mdedge.com/jfponline/article/60464/validating-adult-primary-care-assessment-tool

6. Hauser L, Castro RCL de, Vigo Á, Trindade TG da, Gonçalves MR, Stein AT, et al. Translation, adaptation, validity and reliability of the Instrument for Assessment of Primary Health Care (PCATool) in Brazil: version of health professionals. Rev Bras Med Fam Comun. 2013;8(29):244-55. doi: $10.5712 / \mathrm{rbmfc} 8(29) 821$

7. Zou Y, Zhang X, Hao Y, Shi L, Hu R. General practitioners versus other physicians in the quality of primary care: a cross-sectional study in Guangdong Province, China. BMC Fam Pract. 2015;16(1):1-8. doi: 10.1186/s12875-015-0349-z

8. Macinko J, Jimenez G, Cruz-Peñate M. Primary care performance in Dominica. Rev Panam Salud Publica [Internet]. 2015 [cited 2019 Oct 10];37(2):104-12. Available from: https://www.scielosp.org/article/rpsp/2015.v37n2/104-112/en/\#ModalArticles

9. Bresick GF et al. Western Cape Primary Care Assessment Tool (PCAT) study: Measuring primary care organisation and performance in the Western Cape Province, South Africa (2013). African J Prim Health Care Fam Med. 2016;8(1):e1-12. doi: 10.4102/phcfm.v8i1.1057

10. Pesse-Sorensen K, Fuentes-García A, llabaca J. Estructura y funciones de la Atención Primaria de Salud según el Primary Care Assessment Tool para prestadores en la comuna de Conchalí - Santiago de Chile. Rev Med Chil. 2019;147(3):305-13. doi: 10.4067/S0034-98872019000300305

11. Kemper ES. Avaliação da qualidade da Atenção Primária no Programa Mais Médicos. APS Em Rev.. 2019;1(1):75-87. doi: 10.14295/aps.v1i1.17

12. Nascimento L, Paula CC, Magnago TSBS, Padoin SMM, Harzheim E, Silva CB. Qualidade da atenção primária à saúde de crianças e adolescentes vivendo com HIV. Rev Latino-Am Enfermagem. 2016;24:e2720. doi: 10.1590/1518-8345.0609.2720

13. Ferreira T, Paula CC, Kleinubing RE, Kinalski DF, Anversa ETR, Padoin SMM. Evaluation of the quality of primary health care for children and adolescents with HIV: PCATool-Brasil. Rev Gaúcha Enferm. 2016;37(3):e61132. doi: 10.1590/1983-1447.2016.03.61132

14. Turci MA, Lima-Costa MF, Macinko J. Influência de fatores estruturais e organizacionais no desempenho da atenção primária à saúde em Belo Horizonte, Minas Gerais, Brasil, na avaliação de gestores e enfermeiros. Cad Saúde Pública. 2015;31(9):1941-52. doi: 10.1590/0102-311X00132114

15. Lima EFA, Sousa Al, Leite FMC, Lima RCD, Nascimento MH, Primo CC. Evaluation of the Family Healthcare Strategy from the Perspective of Health Professionals. Esc Anna Nery. 2016;20(2):275-80. doi: 10.5935/1414-8145.20160037

16. Oliveira R, Ida I, Carvalho H, Menezes F. Training and Qualification of Health Professionals: Factors associated to the Quality of Primary Care. Rev Bras Educ Med. 2016;40(4):547-59. doi: 10.1590/1981-52712015v40n4e02492014

17. Maia LG, Silva LA, Guimarães RA, Pelazza BB, Leite GR, Barbosa MA. A qualidade de serviços de atenção primária, a formação profissional e o Programa Mais Médicos em uma região de saúde do sudoeste goiano. Rev Bras Epidemiol. 2020;23:e200014. doi: $10.1590 / 1980-549720200014$

18. Rolim LB, Monteiro JG, Meyer APGFV, Nuto SAS, Araújo MFM, Freitas RWJF. Evaluation of Primary Health Care attributes of Fortaleza city, Ceará State, Brazil. Rev Bras Enferm. 2019;72(1):19-26. doi: 10.1590/0034-7167-2018-0033

19. Martins JS, Abreu SCC, Quevedo MP, Bourget MMM. Comparative Study between Health Care Units with and without Family Health Strategy using PCATool. Rev Bras Med Fam Comun. 2016;11(38):1-13. doi: 10.5712/rbmfc11(38)1252

20. Gomes, MFP, Fracolli, LA. Evaluation of the family health strategy from the professionals' perspective. Rev Bras Promoç Saúde. 2018;31(3):113. doi: $10.5020 / 18061230.2018 .7108$

21. Mazutti Penso J, Périco E, Oliveira MMC, Guimarães Strohschoen AA, Carreno I, Rempel C. Evaluation of Primary Health Care using the PCATool-Brazil Instrument. Rev Bras Med Fam Comun. 2017;12(39),1-9. doi: 10.5712/rbmfc12(39)1212

22. Ministério da Saúde (BR). Portaria no 3.222 de 19 de dezembro de 2019. Dispõe sobre os indicadores do pagamento por desempenho, no âmbito do Programa Previne Brasil. Diário Oficial da União[Internet]. Brasília, p. 172, 11 Dez 2019 [cited 2020 Jan 15]. Available from: http:// www.in.gov.br/en/web/dou/-/portaria-n-3.222-de-10-de-dezembro-de-2019-232670481 
23. Conselho Nacional de Saúde. Resolução 466 de 12 de dezembro de 2012. Dispõe sobre as diretrizes e normas regulamentadoras de pesquisa envolvendo seres humanos. Diário Oficial da União [Internet]. Brasília, p. 59, 13 Jun 2013 [cited 2019 Nov 26]. Seção I. Available from: http://conselho.saude.gov.br/resolucoes/2012/Reso466.pdf

24. Rouquayrol MZ, Almeida Filho N. Epidemiologia \& Saúde. 7. ed. Rio de Janeiro: Medsi, 2013.736p.

25. Instituto Brasileiro de Geografia e Estatística - IBGE. Panorama da cidade de Campina Grande, PB[Internet]. 2019 [cited 2020 May 20]. Available from: https://cidades.ibge.gov.br/brasil/pb/campina-grande/panorama

26. Ministério da Saúde (BR). Datasus. Cadastro Nacional de Estabelecimentos de Saúde [Internet] Brasília (DF); 2019 [cited 2019 Dec 26]. Available from: http://cnes.datasus.gov.br/pages/estabelecimentos/consulta.jsp

27. Ministério da Saúde (BR). Secretária de Atenção Primária à Saúde. e-Gestor: informação e gestão da atenção básica[Internet]. 2019 [cited 2020 May 20]. Available from: https://egestorab.saude.gov.br/paginas/acessoPublico/relatorios/relHistoricoCoberturaAB.xhtml

28. Tesser CD, Norman AH, Vidal TB. Acesso ao cuidado na Atenção Primária à Saúde brasileira: situação, problemas e estratégias de superação. Saúde Debate. 2018;42(1):361-78. doi: 10.1590/0103-11042018s125

29. Ministério da Saúde (BR). Portaria 2.436, de 21 de setembro de 2017. Aprova a Política Nacional de Atenção Básica no âmbito do Sistema Único de Saúde (SUS). [Internet]. Diário Oficial da União. p.68, 22 Dez 2017. [cited 2020 Jan 15] Available from: http://bvsms.saude.gov.br/ bvs/saudelegis/gm/2017/prt2436_22_09_2017.html

30. Massuda A, Hone T, Leles FAG, Castro MC, Atun R. The Brazilian health system at crossroads: progress, crisis and resilience. BMJ Glob Health. 2018;3(4):e000829. doi: 10.1136/bmjgh-2018-000829

31. Tasca R, Massuda A, Carvalho WM, Buchweitz C, Harzheim E. Recommendations to strengthen primary health care in Brazil. Rev Panam Salud Publica. 2020;44(6):e4. doi: 10.26633/RPSP.2020.4

32. Almeida PF, Medina MG, Fausto MCR, Giovanella L, Bousquat A, Mendonça MHM. Coordination of care and Primary Health Care in the Unified Health System. Health Debate. 2018;42(spe1):244-260. doi: 10.1590/0103-11042018s116

33. Carneiro MSM, Melo DMS, Gomes JM, Pinto FJM, Silva MGC. Avaliação do atributo coordenação da Atenção Primária à Saúde: aplicação do PCATool a profissionais e usuários. Saúde Debate. 2014;38(spe):279-295. doi: 10.5935/0103-1104.2014S021

34. Cunha CRH, Harzheim E, Medeiros OL, D'Avila OP, Martins C, Wollmann L. Primary Health Care Portfolio: assuring of integrality in the Family Health and Oral Health Teams in Brazil. Ciênc Saúde Coletiva. 2020;25(4):1313-26. doi: 10.1590/1413-81232020254.31862019

35. Pedraza PF, Queiroz D, Sales MC, Menezes TN. Characterization of work of nurses and health professionals in Support Center for Family Health in Primary Health Care. ABCS Health Sci. 2018; 43(3):77-88. doi: 10.7322/abcshs.v43i2.993

36. Ministério da Saúde (BR). Carteira de Serviços da Atenção Primária à Saúde (CaSAPS). [Internet] Brasília [cited 2020 May 20]. Available from: http://189.28.128.100/dab/docs/portaldab/documentos/casaps_versao_profissionais_saude_gestores_completa.pdf

37. Ministério da Saúde (BR). Política Nacional de Promoção da Saúde - PNaPS: revisão da Portaria MS/GM n 687, de 30 de março de 2006. [Internet] Brasília; 2014 [cited 2020 May 20]. Available from: https://bvsms.saude.gov.br/bvs/saudelegis/gm/2014/prt2446_11_11_2014.html

38. Paula WKAS, Samico IC, Caminha MFC, Batista FM, Figueirôa JN. Orientação comunitária e enfoque familiar: avaliação de usuários e profissionais da estratégia saúde da família. Cad Saúde Colet. 2017;25(2):242-8. doi: 10.1590/1414-462×201700020113

39. Baldani MH, Ribeiro AE, Gonçalves JRSN, Ditterich RG. Processo de trabalho em saúde bucal na atenção básica: desigualdades intermunicipais evidenciadas pelo PMAQ-AB. Saúde Debate. 2018;42(spe1):145-62. doi: 10.1590/0103-11042018S110

40. Fagundes DM, Thomaz EBAF, Queiroz RCS, Rocha TAH, Silva NC, Vissoci JRN. Diálogos sobre o processo de trabalho em saúde bucal no Brasil: uma análise com base no PMAQ-AB. Cad Saúde Pública. 2018;34(9)e00049817. doi: 10.1590/0102-311x00049817

41. Campos KFC, Sena RR, Silva KL. Permanent professional education in healthcare services. Esc Anna Nery. 2017;21(4):e20160317. doi: 10.1590/2177-9465-ean-2016-0317

42. Cavalcanti YW, Padilha WWN. Qualificação de processos de gestão e atenção no município de Caaporã, PB: relatos de tutoria de educação permanente em saúde. Saúde Debate. 2014;38(100):170-80. doi: 10.5935/0103-104.20140009

43. Secretaria de Estado da Saúde da Paraíba. Centro Formador de Recursos Humanos da Paraíba. Resolução CIB. № 01/2019 - Plano Estadual de Educação Permanente em Saúde[Internet] 2019 [cited 2020 May 20]. Available from: https://www.conass.org.br/planos-estaduaiseducacao-permanente/PEEPS-PB.pdf 